Agnese Bankava, $M g$. iur.

University of Latvia, Latvia

Arnis Buka, Dr. iur.

University of Latvia, Latvia

Signe Mezinska, Dr. sc. soc.

University of Latvia, Latvia

Juris Barzdins, Dr. sc. admin.

University of Latvia, Latvia ${ }^{1}$

\title{
THE EFFECT OF GDPR ON SECONDARY USE OF DATA CONCERNING HEALTH IN RESEARCH: LATVIAN CASE IN THE EUROPEAN CONTEXT
}

\begin{abstract}
Summary
The article analyses legal background for using data concerning health (including administrative health data) for research purposes in Latvia in the context of the General Data Protection Regulation (GDPR) ${ }^{2}$. Latvia is used as an example to reflect on how the GDPR interacts with the national legal framework regulating scientific research. The article argues that there are several gaps in regulation requiring systematic amendments, considering both the GDPR and the practical needs of Latvian researchers.
\end{abstract}

Keywords: GDPR, data concerning health, administrative health data, personal data, scientific research

\section{Introduction}

Data concerning health according to the GDPR is "personal data related to the physical or mental health of a natural person, including the provision of health care services, which reveal information about his or her health status." This type of data is an important source of information for medical, epidemiological and health research. During the development of GDPR, there were active discussions about impact of the proposed regulation to medical research, and several researchers

The development of the article was supported by the University of Latvia project "Transparency and health care system data - towards public monitoring for quality and efficiency" (grant No. ZD2017/20443).

2 Regulation (EU) 2016/679 of the European Parliament and of the Council of 27 April 2016 on the protection of natural persons with regard to the processing of personal data and on the free movement of such data, and repealing Directive 95/46/EC (General Data Protection Regulation)

3 Regulation (EU) 2016/679. 
and organizations raised concerns about possible negative impact of GDPR on research ${ }^{4,5,6,7}$. Therefore, the aim of the article is to analyse the possibilities of using data concerning health, including administrative health data, for research purposes in the context of the GDPR, as well as to reflect on how the GDPR influences the legal framework for use of data concerning health for research purposes and interacts with it in Latvia.

\section{GDPR and research using data concerning health: an overview}

In the $21^{\text {st }}$ century, the need for balance between protection of personal data and procession of personal data for public benefit, like analysing the data for health research, gains ever increasing importance. This search for balance is especially manifest within the European Union (EU), which can be regarded as a worldwide example of data protection ${ }^{8}$. The EU not only regards the right to data protection as a part of the right to privacy, but also recognizes within the Article 8 of the Charter of Fundamental Rights of the EU a specific right to the protection of personal data? Even more, it is argued that recognition of a separate fundamental right to data protection guarantees a more comprehensive system of personal data protection ${ }^{10}$.

On the level of EU, secondary legal acts, the balance between the protection of personal data and the procession of these data for research purposes is firmly established. Even so early as during the first discussions on the GDPR, the importance of medical research was mentioned ${ }^{11}$, and the current version of the GDPR includes provisions on the use of the data concerning health in research. However, at the same time, application of GDPR provisions is complicated ${ }^{12}$ and

4 de Jong J. D., Coppen R., Verheij R. A., Groenewegen P. P., Vroom E., van Veen E. B., Reijneveld S. A. Will the trilogue on the EU Data Protection Regulation recognise the importance of health research? European Journal of Public Health, No. 25(5), 2015, pp. 757-758.

5 Nyrén, O., Stenbeck, M., \& Grönberg, H. The European Parliament proposal for the new EU General Data Protection Regulation may severely restrict European epidemiological research. European Journal of Epidemiology, No. 29(4), 2014, pp. 227-230.

6 Ploem M. C., Essink-Bot M. L., \& Stronks K. Proposed EU data protection regulation is a threat to medical research. British Medical Journal, No. 346, 2013, p. 3534.

7 Rumbold J. M. \& Pierscionek B. The Effect of the General Data Protection Regulation on Medical Research. Journal of Medical Internet Research, No. 19(2), 2017, p. 47.

8 Thorogood A. Canada: will privacy rules continue to favour open science? Human Genetics, No. 137(8), 2018, pp. 595-602

9 Fuster G. G. The Emergence of Personal Data Protection as a Fundamental Right of the EU. Vienna: Springer, 2014.

10 Mostert M., Bredenoord A. L., Slootb B. v. d., \& Delden J. J. M. From Privacy to Data Protection in the EU: Implications for Big Data Health Research. European Journal of Health Law, No. 25(1), 2017, pp. 43-55.

11 Pieper F. An outlook on the future of medical research in Europe and data protection: grim or prosperous? European Journal of Health Law, No. 21(3), 2014, pp. 241-244.

12 Dove E. S. The EU General Data Protection Regulation: Implications for International Scientific Research in the Digital Era. The Journal of Law, Medicine \& Ethics, No. 46(4), 2018, pp. 1013-1030. 
the overall design of the national legal framework can be deducted by following the interplay of several provisions of the GDPR.

Article 9 of the GDPR incorporates data concerning health into "special categories of personal data"13, for which there is a presumption that its processing is prohibited. At the same time, part 2 of Article 9 provides a long list of exceptions on when the processing of special categories of personal data is permitted. Mostly those exceptions are related to the consent of data subject or to overriding public interests that justify procession of special categories of personal data.

Of particular importance is point $(j)$ of Article 9(2), which allows to process special categories of personal data, when it is done "for archiving purposes in the public interest, scientific or historical research purposes or statistical purposes"14. However, in this case, too, data processing must be provided in the EU or national legislation and must be proportionate, including the duty of the data processor to take "suitable and specific measures to safeguard the rights and freedoms of the data subject"15.

Article 9(2) (j) of the GDPR also includes a reference to the Article 89, which further explains how to apply the aforementioned conditions to processing special categories of personal data. Among other matters, Article 89 refers to the principle of data minimization explained in the Article 5, namely, that the data must be adequate, relevant and only include what is necessary for the purposes of the processing. Whenever possible, data processing not allowing data subjects to be identified should be given priority. One of the possible safeguards mentioned by the Article 89(1) of the GDPR is the use of pseudonymisation, which is not obligatory, but rather its use is encouraged, if it allows the achievement of research objectives.

Finally, the GDPR includes a preamble with more than 170 recitals, which can be used as an additional tool for interpreting the articles of the GDPR clarifying also the processing of data concerning health for research purposes. Recital 56 of the preamble refers to the main objective that justifies the processing of special categories of personal data - it must be in the public interest. However, the processing of personal data for scientific research is mostly covered by recitals 156 to 159 of the preamble. Recital 159 states that the processing of personal data for research purposes should be interpreted in a broad manner, including technological development and demonstration, fundamental research, applied research and privately funded research. Furthermore, the same recital expressly points out that "scientific research purposes should also include studies conducted in the public interest in the area of public health" ${ }^{16}$. Thus, the recitals in the preamble of the GDPR not only emphasize the importance of collecting data for research purposes but also recognize potential difficulties in full identification of the purpose of the processing of personal data for scientific research at the time of data collection.

13 Regulation (EU) 2016/679.

14 Regulation (EU) 2016/679.

15 Chico V. The impact of the General Data Protection Regulation on health research. British Medical Bulletin, No. 128(1), 2018, pp. 109-118.

16 Regulation (EU) 2016/679. 


\section{Latvian legislation of research using data concerning health: an overview}

Article 288 of the Treaty on the Functioning of the EU ${ }^{17}$ stipulates that all regulations shall have general application and shall be binding in their entirety and directly applicable in all Member States, which also applies to the GDPR. In practice, however, the differences between the directly applicable regulations and directives, which should be transposed into national law, tend to blur. The content of the GDPR is an example of this tendency. While outlining the basic principles of data protection, the GDPR at various places points out to the discretion of Member States to adopt further legislation, providing "an unusually wide margin of maneuver for Member States"18. This includes the field of scientific research and allows to classify requirements of the GDPR in two broad groups: (1) directly applicable research exemptions and (2) research exemptions needing implementation into national law ${ }^{19}$.

In 2018, Latvia adopted the Personal Data Processing Law, Article 2 of which puts forward the aim of the law: "to create legal preconditions for the establishment of the system of protection of personal data at the national level"20. Regrettably, the new law is overly brief regarding regulation of scientific research. Although the law contains Article 31 on the processing of data for scientific or historical research purposes, in substance this article is just a blanket norm referring to the GDPR and copying Article 89 (2) of the GDPR. ${ }^{21}$ Interestingly enough, in the earlier draft version of the Personal Data Processing Law this article contained more detailed provisions for scientific or historical research, stating that certain rights of the data subject are exercised in accordance with the "laws and regulations governing the field of science and research"22 Even this earlier version of the law seems rather vague - what should be understood by laws and regulations governing the field of science and research? However, there is even more ambiguity in the final wording of the Article 31 of Personal Data Processing Law, as any clarifications on how the research exception should be applied are entirely absent.

17 Treaty on the Functioning of the European Union 2012/C 326/01. Signed in Lisbon on 13.12.2007 [in the wording of 26.10.2012].

18 Dove E. S., 2018, p. 1015.

19 van Veen E.B. Observational health research in Europe: understanding the General Data Protection Regulation and underlying debate. European Journal of Cancer, No.104, 2018, pp. 70-80.

20 Fizisko personu datu apstrādes likums [Personal Data Processing Law]. Available at: https:// likumi.lv/ta/id/300099-fizisko-personu-datu-apstrades-likums [last viewed November 2, 2019].

21 Regulation (EU) 2016/679. Exact text of the Article 31: "Where personal data are processed for scientific or historical research purposes, data subject's rights referred to in Articles 15, 16, 18 and 21 of the GDPR shall not apply so far as such rights are likely to render impossible or seriously impair the achievement of those purposes and such derogations are necessary for the achievement of those purposes".

22 Fizisko personu datu apstrādes likums [Personal Data Processing Law (Draft Law)]. Available at: http://tap.mk.gov.lv/doc/2017_10/TMLik_091017_dati.1080.docx [last viewed November 2, 2019]. 
Such a lack of clarification within the Personal Data Processing Law seems to be contrary to the aim of Article 89(2) of the GDPR. It follows from the Article 89(2) ("Where personal data are processed for scientific or historical research purposes or statistical purposes, Union or Member State law may provide for derogations"23) that exceptions to the rights of the data subject for the purposes of research should be explained in detail. This obligation can be regarded as one needing implementation into national $\mathrm{law}^{24}$. Brief and mechanical quoting of the general wording of the GDPR clearly fails to do that.

To complicate matters further, in relation to the use of data concerning health in research the Personal Data Processing Law is not the only relevant piece of Latvian legislation. There is also the Law on the Rights of Patients, ${ }^{25}$ which aims to regulate relationships between the patient and the healthcare provider. The Law on the Rights of Patients has not been amended following the GDPR, but its Article 10 sets out criteria for research use of health data recorded in the medical documents. Article 10(7) and (8) of the Law on the Rights of Patients provide that "patient data recorded in medical documents may be used in a research" in the following three situations:

1) the patient cannot be directly or indirectly identified according to the information to be analysed;

2) the patient has consented in writing that the information regarding him or her may be used in a specific research;

3) if all the following conditions are fulfilled:

- the research is being performed in the public interest;

- a competent State administrative institution has allowed the use of the patient data in a specific research in accordance with the procedures stipulated by the Cabinet;

- the patient has not previously prohibited the transfer of his or her data to a researcher in writing;

- it is not possible to acquire the consent of the patient with commensurate means;

- the benefit of the research for the public health is commensurable with the restriction of the right to the inviolability of private life.

Based on this provision of the Law on the Rights of Patients, the Cabinet of Ministers has issued Regulation No. 446 "Procedures for Using the Patient Data in

23 Regulation (EU) 2016/679.

24 van Veen E. B. 2018.

25 Pacientu tiesību likums [Law On the Rights of Patients]. Available at: https://likumi.lv/ta/ id/203008-pacientu-tiesibu-likums [last viewed November 2, 2019]. 
a Specific Research" ${ }^{26}$ However, that regulation has not been amended in the context of the GDPR.

Thus, in general, the interaction between the most important national legislative acts on the use of data concerning health in research and the GDPR cannot be perceived as thoroughly successful in Latvia. One of these national laws, Personal Data Processing Law, merely makes a formal reference to the GDPR regarding scientific research in a situation where the GDPR rules result in an obligation to provide more detailed legislation at the national level. Another law, the Law on the Rights of Patients has not been amended and harmonized with GDPR.

Moreover, a detailed assessment of the situation shows several ambiguities that are not fully addressed by the existing legal framework and are discussed in greater detail in the next section of the article.

\section{Research using data concerning health: legislative gaps and ambiguities}

\subsection{Concept of "data concerning health"}

Comparing Latvian legal acts and the GDPR, there is a certain ambiguity regarding the definition of "data concerning health". The GDPR gives a broad scope to this term in the recital 35 by including "all data pertaining to the health status of a data subject which reveal information relating to the past, current or future physical or mental health status of the data subject"27. This means that, e.g., administrative data regarding the patient's stay in medical institutions or data of the registers of patients suffering from certain diseases are also covered by the term "data concerning health". On the other hand, Latvian Law On the Rights of Patients uses slightly different terminology. In the context of research, the Latvian law in the Article 10(7) uses the term "medical documents" which, in turn, is explained in the Article 1 as "information [..] regarding a patient, his or her state of health, the diagnosis and prognosis of the illness, the preventive, diagnostic and medical treatment methods used, as well as the results of diagnosis and medical treatment”. Thus, the Law On the Rights of Patients might be interpreted in a narrower way that excludes use of certain administrative data for research purposes.

26 Republic of Latvia Cabinet Regulation No. 446. Kārtỉba, kādā atḷauj izmantot pacienta datus konkrētā pētījumā [Procedures for Using the Patient Data in a Specific Research]. Available at: https://likumi.lv/ta/id/275747-kartiba-kada-atlauj-izmantot-pacienta-datus-konkreta-petijuma [last viewed November 2, 2019].

27 Regulation (EU) 2016/679. 


\subsection{Anonymisation of data}

Section 4 of the GDPR states that data lawfully obtained for any purpose may be used in statistical, scientific or historical research, provided that adequate protective measures are in place. These guarantees may be ensured by anonymisation or pseudonymisation of data prior to sharing of the data with third parties.

The practical situation in Latvia and other European countries currently shows that there is no common understanding of the techniques and criteria to be used in order to anonymize identifiable personal data. Moreover, there may be situations where data subjects can be identified from allegedly anonymous health data sets, for example, by linking health data to other types of information or in cases where the study group is very specific (e.g. rare disease patients). There is also no consensus about detailed requirements for data coding and the storage of code keys. Consequently, a more detailed framework would be required for the way health data is pseudonymised or anonymised, thus introducing appropriate protection measures for health data.

Although the scope of GDPR does not include anonymised data and allows the use of identifiable health data in research under certain conditions, it is often not necessary to identify the data subject directly for scientific research purposes. It is also apparent from Article 89 of the GDPR that data processing, which does not allow data subjects to be identified, should be preferred for research purposes.

\subsection{Use of anonymous data in research}

There is currently no straightforward legal framework in Latvia regulating the use of anonymous health data in research, for example, it is not clear how to use anonymized patient data included in different databases in research. This problem is not raised directly by GDPR, since GDPR does not apply to the processing of data other than personal data. However, this issue must be mentioned in the context of this article, because it is closely linked to the problem that has been addressed above.

There is a legal presumption in Latvia that any anonymized information held by state institutions should be available and shared unless it has a limited accessibility status. Where information requested for research purposes from different databases does not constitute personal data, it shall be subject to the society's right to information. The right to receive information falls within the right to freedom of expression, and information shall be provided to anyone who expresses a wish to receive it. The applicant should not specifically justify his or her interest to receive the information. In practice, however, authorities avoid releasing such data because they fear that this might violate data subjects' right to the protection of personal health data, which results in researchers experiencing difficulties in obtaining such data. 


\subsection{Storing of previously collected administrative health data for research}

Currently, the situation regarding the storage of administrative health data and their secondary use in the public interest is unclear. In fact, following the adoption of the GDPR and in the absence of new regulations specifying this area in Latvia, the storage and subsequent secondary use of the data are threatened. For example, administrative data on services provided to patients and their costs are stored in the National Health Service, but there is no practical need to store these data for a long time in the context of their primary use. At the same time, their potential for secondary use for research in the public interest is very high; therefore, these data should be stored for secondary use, and there should be a possibility to link these data to the data stored by other national authorities (e.g., records of the causes of death) prior to anonymisation. It would be very important to ensure that an appropriate regulatory framework is in place, defining the minimum amount of data to be stored for future research, and a procedure to determine how they might be linked to other types of personal data before anonymisation.

\subsection{Subjects eligible for using health data for research}

Simultaneously with ensuring access to health data for research purposes, the issue of a range of subjects who have a right to request health data for research should be addressed. Currently, broad terms, like "person" or "researcher" are used in the law, and there is a lack of criteria for the required qualifications (e.g., $\mathrm{PhD}$ degree or employment as a researcher). It is not clear, for example, whether students have a right to request health data for research purposes. Additionally, the Cabinet Regulation No. 446 includes a requirement to provide information on the education and experience of the principal investigator and researchers, but there are no criteria for evaluation of this information. The absence of precise regulations on this matter is somewhat compensated by an inter-institutional agreement between four state institutions, all of whom are subordinated to the Ministry of Health (Centre for Disease Prevention and Control, National Health Service, State Emergency Medical Service and Health Inspectorate). Those state institutions have agreed to limit the access to data for scientific research to organisations listed in the Registry of scientific institutions by providing anonymized data link for health care quality monitoring.

One of the reasons why there is a need for a clear definition of subjects having a right to request health data for research is prevention of conflicts of interest by limiting the possibility of using health data for commercial purposes. An important issue is also the opportunity for students to use health data for developing research projects during the studies. To date, several hundred student research projects analysing health data are carried out each year in Latvia, but the GDPR raises the issue of the compliance of such research activities with the GDPR in cases where the person's consent to the processing of data has not been obtained. 


\subsection{Feedback to the institution providing data}

Providing data to researchers is only a single step in the research process, and often the results of the study could be useful for the institution that has provided the health data. Therefore, it would also be necessary to define researcher's duties to the institution providing the data - most likely, in the form of obligation to inform about the results of the study. It should also be considered whether the institution providing the data could, in certain cases, retain the right to control or at least express an opinion on a publication based on the health data issued by this institution. In case of the abovementioned data link for health care quality monitoring, institutions providing the data request the applicant to pre-authorise publication of the study results.

\section{Conclusions}

There are several ambiguities and challenges regarding use of the data concerning health for the research purposes, which are not fully addressed by the existing legal framework in Latvia. Filling in these gaps requires thoughtful and systematic amendments in laws and regulations, taking into account both the GDPR, as well as practical needs of Latvian researchers.

The most ambitious, but at the same time the most comprehensive and transparent solution would be to draft an entirely new piece of legislation. Such an act (law or regulation of the Cabinet of Ministers) should be linked to the preamble and Article 89 of the GDPR, providing appropriate safeguards for the rights and freedoms of the data subject for archiving personal data in the public interest, scientific or historical research or statistical purposes. These safeguards should ensure that all the necessary technical and organizational measures in the sense of the GDPR are in place.

Alternatively, a less ambitious solution might also be applied, namely, amending Latvian legislative acts mentioned in this article (both the laws and Cabinet regulations deriving from these laws).

\section{BIBLIOGRAPHY}

\section{Literature}

1. Chico V. The impact of the General Data Protection Regulation on health research. British Medical Bulletin, No. 128(1), 2018, pp. 109-118.

2. Dove E. S. The EU General Data Protection Regulation: Implications for International Scientific Research in the Digital Era. The Journal of Law, Medicine \& Ethics, No. 46(4), 2018, pp. 1013-1030.

3. Fuster G. G. The Emergence of Personal Data Protection as a Fundamental Right of the EU. Vienna: Springer, 2014. 
4. de Jong J. D., Coppen R., Verheij R. A., Groenewegen P. P., Vroom E., van Veen E. B., Reijneveld S. A. Will the trilogue on the EU Data Protection Regulation recognise the importance of health research? European Journal of Public Health, No. 25(5), 2015, pp. 757-758.

5. Mostert M., Bredenoord A. L., Slootb B. v. d. \& Delden J. J. M. From Privacy to Data Protection in the EU: Implications for Big Data Health Research. European Journal of Health Law, No. 25(1), 2017, pp. 43-55.

6. Nyrén O., Stenbeck M., \& Grönberg H. The European Parliament proposal for the new EU General Data Protection Regulation may severely restrict European epidemiological research. European Journal of Epidemiology, No. 29(4), 2014, pp. 227-230.

7. Pieper F. An outlook on the future of medical research in Europe and data protection: grim or prosperous? European Journal of Health Law, No. 21(3), 2014, pp. 241-244.

8. Ploem M. C., Essink-Bot M. L. \& Stronks, K. Proposed EU data protection regulation is a threat to medical research. British Medical Journal, No. 346, 2013, p. 3534.

9. Rumbold J. M., \& Pierscionek B. The Effect of the General Data Protection Regulation on Medical Research. Journal of Medical Internet Research, No. 19(2), 2017, p. 47.

10. Thorogood A. Canada: will privacy rules continue to favour open science? Human Genetics, No. 137(8), 2018, pp. 595-602.

11. van Veen E. B. Observational health research in Europe: understanding the General Data Protection Regulation and underlying debate. European Journal of Cancer, No. 104, 2018, pp. $70-80$

\section{Legislative acts}

1. Fizisko personu datu apstrādes likums [Personal Data Processing Law]. Available at: https:// likumi.lv/ta/id/300099-fizisko-personu-datu-apstrades-likums [last viewed November 2, 2019].

2. Republic of Latvia Cabinet Regulation No. 446. Kārtība, kādā atḷauj izmantot pacienta datus konkrētā pētijumā [Procedures for Using the Patient Data in a Specific Research]. Available at: https://likumi.lv/ta/id/275747-kartiba-kada-atlauj-izmantot-pacienta-datus-konkreta-petijuma [last viewed November 2, 2019].

3. Pacientu tiesību likums [Law On the Rights of Patients]. Available at: https://likumi.lv/ta/ id/203008-pacientu-tiesibu-likums [last viewed November 2, 2019].

4. Regulation (EU) 2016/679 of the European Parliament and of the Council of 27 April 2016 on the protection of natural persons with regard to the processing of personal data and on the free movement of such data, and repealing Directive 95/46/EC (General Data Protection Regulation).

5. Treaty on the Functioning of the European Union 2012/C 326/01. Signed in Lisbon on 13.12.2007 [in the wording of 26.10.2012].

6. WMA Declaration of Helsinki. Available at: https://www.wma.net/policies-post/wmadeclaration-of-helsinki-ethical-principles-for-medical-research-involving-human-subjects/ [last viewed November 2, 2019]. 